\title{
Article
}

\section{Development of clinical value unit method for calculating patient costs}

Cyganska, Malgorzata, Cyganski, Piotr and Pyke, Chris

Available at http://clok.uclan.ac.uk/28856/

Cyganska, Malgorzata, Cyganski, Piotr and Pyke, Chris ORCID: 0000-00016576-2709 (2019) Development of clinical value unit method for calculating patient costs. Health Economics, 28 (8). pp. 971-983. ISSN 1057-9230

It is advisable to refer to the publisher's version if you intend to cite from the work. http://dx.doi.org/10.1002/hec.3902

For more information about UCLan's research in this area go to

http://www.uclan.ac.uk/researchgroups/ and search for <name of research Group>.

For information about Research generally at UCLan please go to http://www.uclan.ac.uk/research/

All outputs in CLoK are protected by Intellectual Property Rights law, including Copyright law. Copyright, IPR and Moral Rights for the works on this site are retained by the individual authors and/or other copyright owners. Terms and conditions for use of this material are defined in the policies page.

\section{CLoK}

Central Lancashire online Knowledge www.clok.uclan.ac.uk

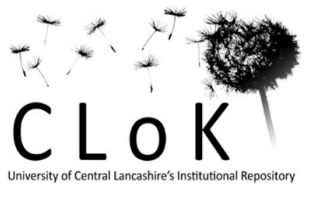




\title{
DEVELOPMENT OF CLINICAL VALUE UNIT METHOD FOR CALCULATING PATIENT COSTS
}

\begin{abstract}
The objective of the study was to develop the Clinical Value Unit method of allocating indirect costs to patient costs using clinical factors. The method was tested to determine whether it is a more reliable alternative to using the Length of Stay and Marginal Mark-up allocation method. The method developed used data from a Polish specialist hospital. The study involved 4,026 patients grouped into nine Diagnosis Related Groups (DRG). The study methodology involved a three stage approach: (i) identification of correlates of patient costs (ii) a comparison of the costs calculated using the Clinical Value Unit method with the alternative methods: Length of Stay and Marginal Mark-up methods and (iii) an estimation of the cost homogeneity of the DRGs. The study showed that Length of Stay cost allocation method may underestimate the proportion of indirect costs in patient costs for a short in-patient stay and overestimate the cost for the patients with a long stay. The total costs estimated using the Marginal Mark-up method were higher than those estimated with Length of Stay method. For most surgical procedures the mean indirect costs are higher using Clinical Value Unit method than when using Length of Stay or Marginal Mark-up method. In all medical procedure cases the mean indirect costs calculated using the Clinical Value Unit method are in the range between Marginal Mark-up and Length of Stay method. We also show that in all DRGs except one, that the coefficient of homogeneity for Clinical Value Unit is higher than for Length of Stay or Marginal Mark-up method. We conclude that the Clinical Value Unit method of cost allocation is a more precise and reliable alternative than the other methods.
\end{abstract}

KEY WORDS: costs, hospital, cost allocation, clinical factors, length of stay, activity based costing. 


\section{Introduction}

Valid financial management decision making in a hospital requires accurate estimates of patient costs. Estimating cost is also important in the assessment for improvement of health system performance. Understanding care costs is challenging due to the highly complex, fragmented, and variable nature of healthcare delivery. In traditional cost accounting systems the most popular cost accounting method is Volume-Based Costing (VBC) (Cao et al., 2006). This top-down approach assumes the division of costs into direct and indirect ones (Chapko et al., 2008). The direct costs are assigned to inpatients based on the actual resource consumption. Direct costs include diagnostics, imaging, laboratory or other diagnostics, drugs, and surgery procedures are assigned to a patient using a bottom-up microcosting method (Wordsworth et al., 2005). Department indirect costs include those costs incurred by medical departments that are not directly related to patients or can not be directly assigned to them and are fixed over the short term (Roberts et al., 1999). Kalman et al. (2015) claim that depending on the measurement methods, between $30 \%$ and $85 \%$ of hospital costs can be considered non-patient care related. This is consitent with the findings of others, for example St-Hilaire et al. (2000) report that indirect costs represent $35 \%-40 \%$ of the total costs of hospital services in Canada, Oostenbrink et al. (2002) have estimated 24\% of indirect costs in the Netherlands hospitals, and Cyganska (2009) reports on 42-60\% in Polish hospitals. Most published studies present the average cost per hospitalisation or cost per inpatient day (Khiaocharoen et al., 2012). Data on the true costs of care for a patient with a particular condition are nearly completely absent (Porter, Lee, 2013). An invalid estimation of indirect costs may completely wipe out the time and effort spent on the cost determination of direct costs. Furthermore, the reliability of accounting information and its usefulness as a tool to measure hospital performance depends on the quality and adequacy of the indirect allocation method. Under VBC there are three steps involved in allocating hospital costs either to individual patients or groups of patient cases which are medically coherent and costhomogeneous: (i) the allocation of hospital overhead costs to medical departments; (ii) the allocation of department overhead costs to patients; and (iii) the allocation of department direct costs to patients. This article will focus on the second and third type of allocation i.e. the allocation of indirect costs to patients using key cost drivers. Tan et al., 2011 describe three methods for assigning the department costs to patients: (i) Marginal Mark-up precentage in which indirect costs are allocated to patients by increasing the direct costs using a mark-up percentage, (ii) weighted statistics, like hourly rate allocation or inpatient day allocation, (iii) Relative Value Units (RVU) in which the relative costs of each patients are established by assigning RVUs. The Marginal Mark-up method is often used by hospitals with a bottom-up approach (Tan, Rutten et al., 2009). Previous studies concluded that Marginal Mark-up allocation with a bottom-up approach may be sufficiently accurate for hospital services which are not expected to vary widely between patients (Tan, Oppe et al., 2009). The popular method of allocating indirect costs to patients is inpatient day allocation (Kludacz-Alessandri, 2017; Polverejan et al., 2003). It is often used in economic evaluations (Gray et al., 2001; Liu et al., 2002). Using this method, the indirect costs are allocated to patients by the length of stay and all the patients are assumed to have the same indirect costs per day regardless of their actual resource use. Taheri et al. (2000) report that length of stay (LOS) is not a good 
surrogate for costs since not all hospital days are economically equivalent. Analysing variations in patient costs it was found that the inpatient costs are associated with LOS, acuity of illness, risk of mortality, social status, age, gender, type of admission, destination after discharge, Intensive Care Unit (ICU) stay and medical factors (Dahl et al., 2012; Pirson et al., 2006). Serra-Batlles et al. (1998) report that the progressive increase in the severity of illness causes a considerable increase in the total costs. Research conducted by Simrova et al. (2014) have revealed that treatment costs significantly differ depending on the selected diagnostic and therapeutic procedures. Other researchers (Popesko et al., 2015) highlight differences between the costs of individual patients under the same diagnosis and their differing demands on hospitals activities.

The alternative method to Marginal Mark-up and LOS method is the RVU methodology. It differentiates the costs, depending on the method of assigning the value base units. RVU establishes the relative cost of each patient by assigning a value to the base-line resource usage of the hospital service and then adding relative values when the patient uses additional resoures. RVUs are a measure of value used to calculate physician reimbursement. RVU denotes physician's time, skill, training and intensity of work going into the production of a service (Raval et al., 2010). This method may reflect the case complexity by incorporating elements of physicians wages. However, RVU, as a component of a fee schedule, might be better turned to capturing aspects relevant to reimbursement rather than to estimating costs (Baadh et al., 2016). Moreover, the physician RVU value is determined by a subjective physician speciality panel and not by objective measurement of actual resource use in practice settings (Goodson, 2007).

The aformentioned approaches to allocating overhead costs within VBC method are easy to use which explains their widespread adoptions. But their ease of use is offset by costing inacuracies. In the mid 1990s, a new costing method was introduced to the healthcare fields called Activity Based Costing System (ABC). ABC was claimed to be the alternative for volume-based cost accounting systems (Cao et al., 2006). This bottom up approach allows the identification of the overhead costs and traces them to each Diagnostic Related Group (DRG)/patient based on consumption of activity resources and thus obtain more accurate cost data (Chapko et al., 2008, Berlin, Smith, 2004). ABC requires detailed analysis of financial accounting records as well as inquires and interviews to identify and gather cost and other information on specific activities. $\mathrm{ABC}$ is particulary relevant for assessing the costs of individual services within complex, integrated healthcare systems like in England or United States (Paulus et al., 2002). Developing and implementing ABC in hospitals is very expensive and time consuming, which may account for its limited adoption (Udpa, 1996; Cardinaels et al., 2004; Emmett, Forget, 2005).

When deciding on the cost allocation method, one must remember that physicians (including clinicians and academic reaserchers) and hospital executives approach the process of patient treatment services from two very different perspectives. The physician sees patients as primarily involving diagnostic and treatment activities, such as diagnostics test, medical procedures. The executive, however, sees the same situation in terms of broader economic and accounting context, such as costs versus charges for the entire patient encounter at the hospital. 
None of the above methods takes into account clinical parameters in the process of allocating hospital costs. Therefore, the purpose of this study was to develop a method of allocating indirect costs to patients using patient characteristics, clinical and treatment factors and explore the variances of inpatient costs given by Clinical Value Units (CVU) and the Length of Stay and the Marginal Mark-up allocation method. In this article, we focus on hospital-based treatment approach, and do not address out-of-hospital care, however the usefulness of the CVU in ambulatory care will be the subject of future studies.

\section{Clinical Value Unit method - conceptual framework}

Estimating costs is important in the assessment required to improve the performance of healthcare systems, as well as improve management effectiveness in hospitals. The need of linking the medical records and cost has been claimed by many authors (Young, Pearlman, 1993; Cyganska 2018). Although the influence of various patient demographic variables, clinical factors and treatment on hospital costs have been widely studied (Uematsu et al., 2015; Gutacker et al., 2013), sophisticated solutions for using these factors in the allocation of overhead costs process have not been developed yet.

Clinical Value Unit method develops a point scale for measuring patient demographic variables, clinical and treatment factors associated with hospital costs. It reflects the relationship between these variables and inpatient treatment costs in hospital. This approach allows simultaneous comparison of the impact on costs of both quantitative and qualitative parameters.

Assessing the variables of in-hospital costs was previously investigated by standard regression model (Polverejan et al., 2003), univariate or multivariate regression analysis (Klein et al., 2008) and logistic regression anaylsis (Cyganska, 2017). To identify the correlates of costs we propose the logistic regression analysis in which the dependent variable is binary, with 'one' denoting patient being a cost outlier $(\mathrm{CO})$ and 'zero' denoting not cost outlier. Cost outliers are identified as patients whose attributes fall outside the $\mathrm{Q}_{3}+1.5 \mathrm{R}$ interval, where Q3 is the third quartile and $\mathrm{R}$ is the interquartile range (quartile deviation). Factors significantly increasing the risk of becoming outlier are identified by logistic regression analysis as follows:

$$
\operatorname{logit} P=\ln \left(\frac{P}{1-P}\right)=\beta_{0}+\sum_{j=1}^{n} \beta_{j} x_{j}
$$

where $\beta$ is the regression coefficient, $x_{j}$ is the independent variable for patient $j=1, \ldots ., n$ (patient demographic variables, clinical and treatment factors), $P$ is the probability of patient becoming cost outlier. To discard the set of independent variables that do not add significantly to the fit of the model, backward stepwise regression is used. The beta coefficients of the normalized parameters in multiple regression analysis are used to build a Clinical Value Unit scale for a qualitative description of patient-related parameters as follows in table 1 . The developed scale illustrates the correlations between the patient characteristics, health condition on admission and hospital treatment vs. patient costs. 
Tab. 1

The number of points scored by every variable in every category is summed up for every patient to produce a synthetic index (CVU). It's based on the identified variables characterizing the patient, the patient's health condition and hospital treatment and describes the cost intensity of treatment as follows:

$$
C V U_{j}=\sum_{i=1}^{m} \beta_{i j}
$$

where $\mathrm{CVU}_{j}$ is the number of Clinical Value Units for patient $j=1, \ldots, n, \beta_{i j}$ - regression coefficient for correlates $i=1, \ldots, m$ of patient $j=1, \ldots, n$. The number of CVUs for all patients in the hospital department is expressed as follows:

$$
C V U=\sum_{j=1}^{n} C V U_{j}
$$

\section{Materials and methods}

\subsection{Data}

We tested the developed method using data from the Provincial Specialized Hospital in Olsztyn, Poland. The hospital provides diagnostics, therapy, care, specialist advice, education, prevention, and health promotion. It is the biggest public hospital in the region financed by the National Health Fund (NFZ). The hospital has 455 beds, more than 130,000 outpatient visits per year and more than 15,000 inpatient admissions per year with occupancy rates about 80 percent. Between January and June 2016 there were 5,367 patients admitted to the Departments of Cardiology, Laryngology, Ophthalmology, Nephrology, ICU, Gastroenterology, Orthopedics, Surgery, Neurosurgery, Gynecology, Endocrinology, Diabetology and Hematology. We reviewed all of the patients that were admitted to the hospital departments during a 6-month period, except newborns $(n=457)$. Some of the patients were excluded from the analysis because of missing data $(n=365)$. Finally, we have included 4,026 patients grouped into nine high volume Diagnosis Related Groups (DRG)* (Table 2).

Tab. 2

The study methodology involved a three stage approach: (i) identification of cost variables (ii) a comparison of the estimated costs using the CVU with the LOS and Marginal Mark-up methods and (iii) an estimation of the cost homogeneity of the DRGs. Each of these steps is explained in details below.

\footnotetext{
* The Polish Diagnosis Related Group system was introduced in 2003 and is based on the English system called Human Recource Group (HRG 3.5 version).
} 


\subsection{Identification of cost allocation factors}

Data were obtained from two computerized databases: administrative and medical. We considered age, LOS, gender, type of admission, reason for discharge, Intensive Care Union (ICU) stay and the number of departments that the patient was treated on as the possible factors that may influence the hospital costs. Annual direct and overhead costs were taken from the annual accounts of the hospital departments. All costs were based on the 2016 cost data. Cost in PLN were converted to euro on the basis of average exchange rate of NBP (Polish National Bank) from 31.01.2017 (1€=4.3308 PLN). We selected a cost allocation based on the factors that significantly affect the direct costs of the patients. Using multiple regression analysis with a backward stepwise regression method (Johnson et al., 2002). A significance level of 0.05 was adopted as the criterion for entering the factors into the regression model. Univariate regression analysis was performed to assess the association between direct costs and each of the factors listed above. Statistical analysis was carried out using STATISTICA, version 13.3, StatSoft, Inc. (2011).

\subsection{The methodologies}

\subsubsection{CVU method}

We established the clinical value units for each patient based on the predetermined cost allocation factors. We then used multivariate logistic regression analysis to separate the relationship between the $\mathrm{CO}$ (dependent variable) and treatment characteristics as explanatory variables (Tan, Oppe et al., 2009). The $\beta$ coefficients of the explanatory variables that were significantly associated with the CO were assumed as the basis of allocating the overhead costs to the individual patients. Each patient was assigned a relative unit. Total CVUs were calculated by multiplying the number of variables and its CVU.

\subsubsection{Length of stay allocation method}

When we calculated the length of stay allocation, all patients were assumed to have the same indirect costs per day regardless of their actual resource usage. The annual indirect costs were divided by the total number of inpatient days in 2016 to calculate the unit costs per inpatient day.

\subsubsection{Marginal Mark-up allocation method}

When we calculated the Marginal Mark-up allocation, indirect costs are distributed to the patients by increasing the direct costs with a mark-up percentage, which was determined by dividing annual indirect costs by annual direct costs.

\subsubsection{A Comparison of methodologies}

In addition to descriptive statistics, Wilcoxon's signed rank test was used to compare the three methods for each DRG. A $p$-value of less than 0.05 was considered statistically significant. The "goodness of fit" in each estimation was analyzed by the coefficient of determination. All costs are expressed in Euros. The distribution of continuous data was expressed by mean \pm standard deviation if appropriate. 


\subsection{Estimation of the cost homogeneity of DRGs}

To quantify improvements in the cost calculation we used the reduction in the variance of costs. We analyzed cost homogeneity of DRGs using the coefficient of homogeneity $(\mathrm{CH})$. A $\mathrm{CH}$ of 1 indicates full homogeneity, whereas a $\mathrm{CH}$ close to 0 indicates no homogeneity (Vogl, 2012).

\section{Results}

Multivariate logistic regression model results in Table 3 shows that age, gender, LOS, ICU stay and the inter-department treatment increase a patient's probability of being CO.

Tab. 3

The probability of being $\mathrm{CO}$ increased more than 2.5 times with each subsequent day of stay in hospital, more than $36 \%$ for patients that stayed in ICU, and more than $10 \%$ for male patients. We used beta coefficients to calculate Clinical Value Units for a qualitative description of patient-related parameters. In table 4 we presented the number of points scored by each variable summed up for every patient within DRG.

Tab. 4

The mean CVU reflects that the most cost-consuming, regarding risk factors of being $\mathrm{CO}$, are women classified in N03, and the least cost-consuming are patients from M15.

We used CVU to allocate overhead costs to patient within DRG. As can be seen in Table 5 for N09 the CVU method resulted in indirect costs of $€ 1111.80$ (SD 419.97). The proportion of direct and indirect cost components to total costs was $41.21 \%$ and $58.79 \%$ respectively. The indirect estimates of LOS method were much higher than the CVU method ( $€$ 1971.76). The proportion of indirect cost components was 71.67\%. The Marginal Mark-up method resulted in overhead cost $43.68 \%$ lower from CVU and $68.25 \%$ lower from LOS method.

In all analyzed DRG groups the Marginal Mark-up method resulted in 41-44\% proportion of indirect costs to total costs. The proportion of indirect costs in total costs ranged from $24.81 \%$ to $82.27 \%$ for LOS method and from $28.30 \%$ to $84.65 \%$ for CVU method.

Tab 5

As can be seen in Table 5 in all cases the difference between CVU method, LOS method and Marginal Mark-up method was statistically siginficant. In all DGR Groups but one, the mean costs was higher for CVU compared to Marginal Mark-up method. The mean cost of treatment for patients with a longer stay in hospital was higher for the LOS method in comparison to CVU method. In the case of patients from DRG groups with a shorter stay the mean cost for LOS method was lower than for CVU method.

To quantify improvements in cost calculation methods we analyzed cost homogeneity of DRGs using the coefficient of homogeneity (Table 6).

\section{Tab 6}


We observed that in all DRG Groups but one (N09) the CH was higher for CVU method in comparison to LOS and Marginal Mark-up method. The range of $\mathrm{CH}$ for Marginal Mark-up method was $0.4386-0.8149$, for LOS method 0.6235 - 0.7760 and for CVU method 0.64440.8843 .

\section{Discussion of Results}

\subsection{A comparison of estimation}

The allocation of indirect costs based on the length of stays is a popular method used in healthcare accounting systems (Fattore et al., 2004; Needleman et al., 2006, Behner et al., 1990). However, conventional hospital cost system can report seriously distorted cost per patient when patient care is diverse in terms either level of acuity or amount of care. For example patients with short stays but who require extensive nursing suport uses more recources than patients who require long stays with minimal nursing attention (Udpa, 1996). Our study shows that LOS cost allocation method may underestimate the proportion of indirect costs allocated to hospital services for a short inpatient stay (B19, E27) and overestimate the cost for long stay patients (N09, N07D, N03). We also revealed that the cost of DRG with high average LOS (N09, A48, N03) were twice as high as those using LOS method or using the Marginal Mark-up method, which is consistant with Tan, Rutten et. al. (2009) findings. The high percentage of cost distribution based on LOS especially influences the cost of medical DRGs (conservative therapy) where the fraction of directly case-related costs is low compared with operative DRGs. Marginal Mark-up method is used for allocating overhead and capital cost in micro-costing approaches (Al et al., 2010). The difference between Marginal Mark-up method and LOS method is not significant in terms of small surgery procedures (B19, E 27, B18). We presume that this is because of short stay patients (LOS ranged from 1.96-2.69) and low direct costs (ranged from $394.95 €$ to $476.91 €$ ). We observed that the more complex procedures cause higher direct costs (E12), which is consistent with Davenport et. al. (2005) findings. That's why the total costs estimated with Marginal Mark-up method are higher than estimated with LOS method. It is also consistent with Dindo et al. (2004) study which demonstrated that the complexity of surgery is significantly correlated with length of hospital stay and the occurrence of complications. In addition, Wang et al. (2009) proved that there is a correlation between the occurrence of complications and the level of direct costs. For most surgical procedures (M15, B19, E27, B18) the mean indirect costs is higher for the CVU method than for LOS or Marginal Markup method. For all the medical procedures (N09, N07D, A48, N03) the mean of indirect costs calculated by CVU method is in the range between Marginal Mark-up and LOS method. Carreras et al. (2011) reported that the selection of an overhead allocation methodology does not produce significant distortion of results. Our study didn't confirm this finding, indeed the CVU method is significantly different from LOS method and Marginal Mark-up method. We revealed that in all DRG but one (N09) the $\mathrm{CH}$ for CVU is higher than for LOS or Marginal Mark-up method. The positive influence of the cost allocation method on coefficient of homogeneity was also described by Vogl (2013). We believe that this method reflects most closely actual resource consumption and is a good alternative for LOS and Marginal Mark-up method.

\subsection{Implications}

Although specific costs, as well as predetermined cost allocation factors may be unique at each hospital, the applicability of this method is generalizable. The CVU method is a window into understanding and quantifying the variation in resource use in hospitals. It provides a 
reasonable compromise between accuracy and ease of implementation in estimating patient level costs.

Cost differences between the hospital services are determined by costing methodology and actual performacne of the hospital (Drummond et al., 2005). Because the level of accuracy of cost estimates is determined by both, the identification and valuation of cost copmponenets, the results of CVU method will be determined by approach to resource used employment for a patient in hospital. The CVU method may be a strong alternative to traditional indirect cost allocation methods in hospitals that are likely to show wide cost variation between patients as the consequences of their health condition. As the reliability of cost estimates is determined by the share of overheads in total hospital costs (Tan, Rutten et al., 2009), we conclude that the use of CVU method should be especially considered for hospitals with a large cost component of labour and overheads. Latimer et al. (1995) emphasize that a reasonable balance must be struck between the resources used to allocate direct costs and those used to allocate indirect costs. This is because the higher level of indirect costs, the greater significance of the indirect cost allocation method on costs estimates. The results of CVU method and its' relations to Length of Stay and Marginal Mark-up methods may produce different results in different hospitals, depending on the cost structure. Hovewer, to determine to what extent the level of direct costs influance on (minimise or maximise) the role of indirect cost allocation method, future studies are needed.

CVU method can also be adopted in examining the average cost per DRG. By integrating data describing patient characteristics, health condition and hospital treatment with costs, the hospital managers and also clinicians can begin to understand where there is variation in treatment for individual medical conditions

For both research and clinical applications, it is important to test the roboustness of the results. For example, costs calculated through the CVU method can be used in the cost portion of a cost effectiveness or cost benefit analysis. A sensitivity analysis can then be performed to determine how the outcomes, and therefore decisions, might vary when certain parameters, like the percentage of hospital complications, are changed. CVU can provide the type of evidence-based outcomes that will assists the hospital services in creating best practice application for use in setting acceptable standards of care. When the CVU method is combined with clinical pathways, managers and clinicians can focus on improving quality of healthcare and reducing costs. For example using the CVU method managers can assess the impact of adverse events on the hospital costs in terms of incurring additional expenses or preventability. The importance of CVU method may increase particulary in those areas where pricing is based on diagnosis related groups, as the effective operation of this concept depends largely on the proper cost accounting system, which ensures the cost homogeneity of individual groups (Feyrer et al., 2005; Raulinajtys-Grzybek, 2014).

In this paper, we focused on hospital-based treatment approach. The CVU method can be also used in Emergency Department (ED), as the need for transparent method for allocating EDs' overhead costs, has been claimed by many authors (April \& Murray, 2017). However, patient-related parameters used to build a Clinical Value Unit scale in ED may differ.

\subsection{Limitations of the CVU method}

Clinical Value Unit method has limitations. It should not be viewed as a method to fix hospital costs, but rather as a tool to help managers and clinicians to measure patient costs and refare them to patient characteristics, health condition on admission and hospital treatment process. Implementing CVU method requires an initial effort to collect medical records and integrate them with accounting system. Some of the medical information may already be in IT system and need just to be linked to patient records, others will need to be covered by the IT system. However, the advantage of CVU method that one can use data available in the 
hospital information system. But it must be kept in mind that the more data on the input, the more accurate results.

\section{Limitations of the study}

We considered age, LOS, gender, type of admission, reason for discharge, Intensive Care Union (ICU) stay and the number of departments that the patient was treated on, as the possible factors that may influence the hospital costs. Other variables presented in the conceptual framework were not covered in the analysis because of limited data within the hospital information system.

\section{Conclusions}

The causal relationship between resource use and treatment is limited when standard principles of calculating patient costs are used. This is because indirect costs are generally calculated on the assumption that the duration of hospitalization is the only factor that drives resource use. In fact not all hospital days are economically equivalent, and length of stay is not the only factor influencing costs. The developed CVU method largely resolves this problem by introducing patient-related parameters, the patient's health condition on admission and hospital course in the process of calculating treatment costs. The costing study demonstrates that the selection of an overhead allocation methodology produces significantly different results. Although LOS and Marginal Mark-up allocation methods are acceptable from an accounting perspective, developed method reports more accurate costs than conventional systems, provides more detailed information related to patients and is more convenient and not as complex as ABC. Popular overhead allocation methods like LOS method or Marginal Mark-up method can overestimate or under estimate the proportion of indirect costs. We conclude that CVU method is a more precise and reliable alternative to the Length of Stay and Marginal Mark-up allocation method.

\section{Conflict of interest}

The authors have no conflict of interest.

\section{Acknowledgments}

We thank two anonymous referees for their comments and suggestions.

\section{References}

Al, M. J., Hakkaart, L., Tan, S., \& Bakker, J. (2010). Cost-consequence analysis of remifentanil-based analgosedation vs. conventional analgesia and sedation for patients on mechanical ventilation in the Netherlands. Critical Care, 14(6), R195.

April, M. D., \& Murray, B. P. (2017). Cost- effectiveness Analysis Appraisal and Application: An Emergency Medicine Perspective. Academic Emergency Medicine, 24(6), 754-768.

Baadh, A., Peterkin, Y., Wegener, M., Flug, J., Katz, D., \& Hoffmann, J. C. (2016). The relative value unit: history, current use, and controversies. Current problems in diagnostic radiology, 45(2), 128-132.

Behner, K.G., Fogg, L.F., Fournier, L.C., Frankenbach, J., \& Robertson, S.B.(1990). Nursing resource management: Analyzing the relationship between costs and quality in staffing decisions. Healthcare Management Review, 15, 63-71.

Berlin, M. F., \& Smith, T. H. (2004). Evaluation of activity-based costing versus resource-based relative value costing. The Journal of Medical Practice Management: MPM, 19(4), 219-227.

Cao, P., Toyabe, S. I., \& Akazawa, K. (2006). Development of a practical costing method for hospitals. The Tohoku journal of experimental medicine, 208(3), 213-224.

Cardinaels, E., Roodhooft, F., \& Van Herck, G. (2004). Drivers of cost system development in hospitals: results of a survey. Health Policy, 69(2), 239-252. 
Carreras, M., García-Goñi, M., Ibern, P., Coderch, J., Vall-Llosera, L., \& Inoriza, J. M. (2011). Estimates of patient costs related with population morbidity: can indirect costs affect the results?. The European Journal of Health Economics, 12(4), 289-295.

Chapko, M. K., Liu, C. F., Perkins, M., Li, Y. F., Fortney, J. C., \& Maciejewski, M. L. (2009). Equivalence of two healthcare costing methods: bottom- up and top- down. Health economics, 18(10), 1188-1201.

Cyganska, M. (2009). Kalkulacja kosztów w Szpitalu Powiatowym Województwa Warmińsko-Mazurskiegostudium przypadku. Zeszyty Teoretyczne Rachunkowości, 48(104), 5-16.

Cyganska, M. (2017). Analysis of high cost outliers in a polish reference hospital, Ekonomika a Management, 4, XX, DOI: 10.15240/tul/001/2017-4-005

Cyganska, M. (2018). Integracja informacji finansowych i klinicznych na potrzeby zarzadzania operacyjnego szpitalem, Wydawnictwo UWM, Olsztyn.

Dahl, D., Wojtal, G.G., Breslow, M.J., Holl, R., Huguez, D., Stone, D., \& Korpi, G. (2012). The High Cost of Low-Acuity ICU Outliers. J Healthc Manag, 57(6), 421-33.

Davenport, D. L., Henderson, W. G., Khuri, S. F., \& Mentzer Jr, R. M. (2005). Preoperative risk factors and surgical complexity are more predictive of costs than postoperative complications: a case study using the National Surgical Quality Improvement Program (NSQIP) database. Annals of surgery, 242(4), 463.

Dindo, D., Demartines, N., \& Clavien, P. A. (2004). Classification of surgical complications: a new proposal with evaluation in a cohort of 6336 patients and results of a survey. Annals of surgery, 240(2), 205.

Drummond, M. F., Sculpher, M. J., Claxton, K., Stoddart, G. L., \& Torrance, G. W. (2015). Methods for the economic evaluation of health care programmes. Oxford University Press.

Emmett, D., \& Forget, R. (2005). The utilization of activity-based cost accounting in hospitals. Journal of Hospital Marketing \& Public Relations, 15(2), 79-89.

Fattore G, Torbica A. HealthBasket - health benefits and service costsin Europe, SP21-CT-2004-501588. In: Approaches for cost/priceassessment in practice. Italy: County report; 2005. http://www.ehma.org/files/WP 6 HealthBASKETSP21 CT 2004501588 D15Italy.pdf [accessed 26.02.14].

Feyrer, R., Rösch, J., Weyand, M., \& Kunzmann, U. (2005). Cost unit accounting based on a clinical pathway: a practical tool for DRG implementation. The Thoracic and Cardiovascular Surgeon, 53(05), 261-266.

Goodson, J. D. (2007). Unintended consequences of resource-based relative value scale reimbursement. Jama, 298(19), 2308-2310.

Gray, A., Clarke, P., Raikou, M., Adler, A., Stevens, R., Neil, A., .. \& Holman, R. (2001). An economic evaluation of atenolol vs. captopril in patients with Type 2 diabetes (UKPDS 54). Diabetic medicine, 18(6), 438-444.

Gutacker, N., Bojke, C., Daidone, S., Devlin, N. J., Parkin, D., \& Street, A. (2013). Truly Inefficient or Providing Better Quality of Care? Analysing the Relationship Between Risk- Adjusted Hospital Costs and Patients' Health Outcomes. Health Economics, 22(8), 931-947.

Johnson, R. A., \& Wichern, D. W. (2002). Applied multivariate statistical analysis (Vol. 5, No. 8). Upper Saddle River, NJ: Prentice hall.

Kalman, N., Hammill, B., Schulman, K., \& Shah, B. (2015). Hospital overhead costs: the neglected driver of health care spending?. Journal of Health Care Finance, 41(4).

Khiaocharoen, O., Pannarunothai, S., Riewpaiboon, A., \& Zungsontiporn, C. (2012). Estimating patient-level costs for acute and sub-acute inpatient services in Thailand. Siriraj Medical Journal, 64(5), 157-162.

Klein, M. B., Hollingworth, W., Rivara, F. P., Kramer, C. B., Askay, S. W., Heimbach, D. M., \& Gibran, N. S. (2008). Hospital costs associated with pediatric burn injury. Journal of Burn Care \& Research, 29(4), 632637.

Kludacz-Alessandri, M. (2017). Impact of cost calculation quality on hospital performance. European Financial Systems, 2017, 326.

Latimer, E. A., \& Kane, N. M. (1995). Practice expenses in the MFS: the service-class approach. Health Care Financing Review, 16(3), 197.

Liu, J. L. Y., Maniadakis, N., Gray, A., \& Rayner, M. (2002). The economic burden of coronary heart disease in the UK. Heart, 88(6), 597-603.

Needleman, J., Buerhaus, P. I., Stewart, M., Zelevinsky, K., \& Mattke, S. (2006). Nurse staffing in hospitals: is there a business case for quality?. Health Affairs, 25(1), 204-211.

Oostenbrink, J. B., Koopmanschap, M. A., \& Rutten, F. F. (2002). Standardisation of Costs. Pharmacoeconomics, 20(7), 443-454.

Paulus, A., van Raak, A., \& Keijzer, F. (2002). ABC: The pathway to comparison of the costs of integrated care. Public Money and Management, 22(3), 25-32.

Pirson, M., Dramaix, M., Leclercq, P., \& Jackson, T. (2006). Analysis of cost outliers within APR-DRGs in a Belgian general hospital: Two complementary approaches. Health Policy, 76 (1), 13-25

Polverejan, E., Gardiner, J. C., Bradley, C. J., Holmes- Rovner, M., \& Rovner, D. (2003). Estimating mean hospital cost as a function of length of stay and patient characteristics. Health Economics, 12(11), 935-947. 
Popesko, B., Papadaki, S., \& Novak, P. (2015). Cost and reimbursement analysis of selected hospital diagnoses via activity-based costing. Ekonomika a Management, 18, (3), 50-60. DOI: 10.15240/tul/001/2015-3-005

Porter, M. E., \& Lee, T. H. (2013). The strategy that will fix health care. Harvard Business Review, 91(10), 1-19.

Raulinajtys-Grzybek, M. (2014). Cost accounting models used for price-setting of health services: an international review. Health Policy, 118(3), 341-353.

Raval, M. V., Cohen, M. E., Ingraham, A. M., Dimick, J. B., Osborne, N. H., Hamilton, B. H., ... \& Hall, B. L. (2010). Improving American College of Surgeons National Surgical Quality Improvement Program risk adjustment: incorporation of a novel procedure risk score. Journal of the American College of Surgeons, 211(6), 715-723.

Roberts, R. R., Frutos, P. W., Ciavarella, G. G., Gussow, L. M., Mensah, E. K., Kampe, L. M., ... \& Rydman, R. J. (1999). Distribution of variable vs fixed costs of hospital care. Jama, 281(7), 644-649.

Serra-Batlles, J., Plaza, V., Morejon, E., Comella, A., \& Brugues, 1. (1998). Costs of asthma according to the degree of severity. European Respiratory Journal, 12(6), 1322-1326.

Simrova, J., Bartak, M., Vojtisek, R., \& Rogalewicz, V. (2014). The costs and reimbursements for lung cancer treatment among selected health care providers in the czech republic. Ekonomika a Management, 17, (3), 7485. DOI: $10.15240 /$ tul/001/2014-3-007.

St-Hilaire, C., \& Crépeau, P. K. (2000, July). Hospital and unit cost allocation methods. In Healthcare Management Forum (Vol. 13, No. 2, pp. 25-32). Sage CA: Los Angeles, CA: SAGE Publications.

Taheri, P.A., Butz, D.A., \& Greenfield, L.J. (2000). Length of stay has minimal impact on the cost of hospital admission. J Am Coll Surg, 191 (2), 123-130.

Tan, S. S., Oppe, M., Zoet-Nugteren, S. K., Niezen, R. A., Kofflard, M. J. M., Ten Cate, F. J., \& Hakkaart-van Roijen, L. (2009). A microcosting study of diagnostic tests for the detection of coronary artery disease in the Netherlands. European Journal of Radiology, 72(1), 98-103.

Tan, S. S., Rutten, F. F. H., Van Ineveld, B. M., Redekop, W. K., \& Hakkaart-van Roijen, L. (2009). Comparing methodologies for the cost estimation of hospital services. The European Journal of Health Economics, 10(1), 39-45.

Tan, S. S., Serdén, L., Geissler, A., van Ineveld, M., Redekop, K., Heurgren, M., \& Hakkaart-van Roijen, L. (2011). DRGs and cost accounting: which is driving which. Busse., R., Geissler, A., Quentin, W., Wily, M.(Eds.) Diagnosis-related groups in Europe: moving towards transparency, efficiency and quality in hospitals. Buckingham, Open University Press and WHO Regional Office for Europe,(2011a), 59-74.

Udpa, S. (1996). Activity-based costing for hospitals. Health Care Management Review, 21(3), 83-96.

Uematsu, H., Kunisawa, S., Yamashita, K., \& Imanaka, Y. (2015). The Impact of Patient Profiles and Procedures on Hospitalization Costs through Length of Stay in Community-Acquired Pneumonia Patients Based on a Japanese Administrative Database. PLOS ONE, 10(4). DOI:10.1371/journal.pone.0125284.

Vogl, M. (2012). Assessing DRG cost accounting with respect to resource allocation and tariff calculation: the case of Germany. Health Economics Review, 2(1), 15.

Vogl, M. (2013). Improving patient-level costing in the English and the German 'DRG'system. Health Policy, 109(3), 290-300.

Wang, W., Fu, C. W., Pan, C. Y., Chen, W., Zhan, S., Luan, R., .. \& Xu, B. (2009). How do type 2 diabetes mellitus-related chronic complications impact direct medical cost in four major cities of urban China?. Value in Health, 12(6), 923-929.

Wordsworth, S., Ludbrook, A., Caskey, F., \& Macleod, A. (2005). Collecting unit cost data in multicentre studies. The European Journal of Health Economics, 6(1), 38-44.

Young, D. W., \& Pearlman, L. K. (1993). Managing the stages of hospital cost accounting. Healthcare Financial Management: Jjournal of the Healthcare Financial Management Association, 47(4), 58-60. 
Tab. 1. Estimation of Clinical Value Units (CVU)

\begin{tabular}{|c|c|c|c|c|}
\hline $\begin{array}{c}\text { Parameters } \\
\text { describing the } \\
\text { patient and hospital } \\
\text { treatment }\end{array}$ & Correlates & Explaining variables & Variable & $\begin{array}{c}\text { Beta } \\
\text { coefficient }\end{array}$ \\
\hline \multirow{6}{*}{$\begin{array}{l}\text { Demographic and } \\
\text { social data }\end{array}$} & Gender & $\begin{array}{l}\text { Female } \\
\text { Male }\end{array}$ & $\mathrm{X}_{1}$ & $\beta_{1}$ \\
\hline & Age (years) & & $\mathrm{X}_{2}$ & $\beta_{2}$ \\
\hline & Substance abuse & $\begin{array}{l}\text { Smoking } \\
\text { Alcohol } \\
\text { Other }\end{array}$ & $\begin{array}{l}X_{3} \\
X_{4} \\
X_{5}\end{array}$ & $\begin{array}{l}\beta_{3} \\
\beta_{4} \\
\beta_{5}\end{array}$ \\
\hline & Family history & $\begin{array}{l}\text { Patient lives with family } \\
\text { Patient lives alone }\end{array}$ & $\begin{array}{l}X_{6} \\
X_{7}\end{array}$ & $\beta_{6}$ \\
\hline & $\begin{array}{c}\text { Living } \\
\text { conditions }\end{array}$ & $\begin{array}{l}\text { Welfare recipient } \\
\text { Homeless }\end{array}$ & $\begin{array}{l}\mathrm{X}_{8} \\
\mathrm{X}_{9}\end{array}$ & $\beta_{7}$ \\
\hline & $\begin{array}{c}\text { Professional } \\
\text { activity }\end{array}$ & $\begin{array}{l}\text { Professionally active } \\
\text { Unemployed }\end{array}$ & $\begin{array}{l}\mathrm{X}_{10} \\
\mathrm{X}_{11}\end{array}$ & $\beta_{8}$ \\
\hline \multirow[t]{3}{*}{$\begin{array}{l}\text { Health condition on } \\
\text { admission }\end{array}$} & $\begin{array}{c}\text { Type of } \\
\text { admission }\end{array}$ & $\begin{array}{l}\text { Planned admission } \\
\text { Emergency admission - } \\
\text { ER } \\
\text { Urgent admission - } \\
\text { Medical Emergency Unit } \\
\text { Inter-hospital transfer }\end{array}$ & $\mathrm{X}_{12}$ & $\beta_{12}$ \\
\hline & $\begin{array}{c}\text { Functional } \\
\text { independence } \\
\text { on admission }\end{array}$ & $\begin{array}{l}\text { Independent } \\
\text { Moderately independent } \\
\text { Dependent }\end{array}$ & $\mathrm{X}_{13}$ & $\beta_{13}$ \\
\hline & Comorbidities & & $\mathrm{X}_{14}$ & $\beta_{14}$ \\
\hline \multirow{6}{*}{ Hospital treatment } & $\begin{array}{l}\text { Undesirable } \\
\text { events }\end{array}$ & $\begin{array}{l}\text { Hospital-acquired } \\
\text { infections } \\
\text { Surgical complications } \\
\text { Bed sores } \\
\text { Other } \\
\end{array}$ & $\begin{array}{l}\mathrm{X}_{15} \\
\mathrm{X}_{16} \\
\mathrm{X}_{17} \\
\mathrm{X}_{18}\end{array}$ & $\beta_{15}$ \\
\hline & Length of stay (d & & $\mathrm{X}_{19}$ & $\beta_{16}$ \\
\hline & \multirow{2}{*}{ Diet } & $\begin{array}{l}\text { Standard diet } \\
\text { Nutritional therapy }\end{array}$ & $\mathrm{X}_{20}$ & $\beta_{17}$ \\
\hline & & $\begin{array}{l}\text { Enteral nutrition } \\
\text { Parenteral nutrition }\end{array}$ & $\mathrm{X}_{21}$ & $\beta_{18}$ \\
\hline & \multicolumn{2}{|c|}{ Inter-ward transfer (number of wards) } & $\mathrm{X}_{22}$ & $\beta_{19}$ \\
\hline & $\begin{array}{l}\text { Reason of } \\
\text { discharge }\end{array}$ & $\begin{array}{l}\text { End of diagnostic and } \\
\text { therapeutic process } \\
\text { Follow-up outpatient } \\
\text { treatment } \\
\text { Inter-hospital transfer } \\
\text { Discharge against medical } \\
\text { advice } \\
\text { Death }\end{array}$ & $\mathrm{X}_{23}$ & $\mathrm{~B}_{20}$ \\
\hline
\end{tabular}


Tab. 2 Nine high volume DRGs in hospital in 2016

\begin{tabular}{clccc} 
DRG & \multicolumn{1}{c}{ Description } & $\begin{array}{c}\text { Number } \\
\text { of cases }\end{array}$ & $\begin{array}{c}\text { Length } \\
\text { of stay }\end{array}$ & Diagnosis \\
\hline N09 & $\begin{array}{l}\text { Severe pregnancy pathology with delivery - extended } \\
\text { diagnostics, comprehensive treatment }>10 \text { days }\end{array}$ & 645 & 13.24 & Medical \\
\hline M15 & Small surgery on the upper part of the reproductive system & 629 & 1.06 & Surgical \\
\hline B19 & $\begin{array}{l}\text { Removal of unspecified cataract with simultaneous implantation } \\
\text { of the lens }\end{array}$ & 619 & 1.96 & Surgical \\
\hline E27 & Coronary angiography and other invasive procedures & 476 & 2.69 & Surgical \\
\hline E12 & Acute Coronary Syndromes - complex invasive treatment & 438 & 4.48 & Surgical \\
\hline B18 & $\begin{array}{l}\text { Removal of cataract complicated with simultaneous implantation } \\
\text { of the lens }\end{array}$ & 396 & 2.29 & Surgical \\
\hline N07D & $\begin{array}{l}\text { Severe pregnancy pathology - extended diagnostics, } \\
\text { comprehensive treatment }>\text { 4 days }\end{array}$ & 346 & 9.49 & Medical \\
\hline A48 & Comprehensive stroke treatment> 7 days in stroke department & 292 & 10.94 & Medical \\
\hline N03 & $\begin{array}{l}\text { Pathology of pregnancy or fetal delivery> 5 days } \\
\text { DRG - Diagnosis Related Groups }\end{array}$ & 185 & 37.96 & Medical
\end{tabular}


Tab. 3 Multivariate ligistic regression model to define Clinical Value Units for the CVU method

\begin{tabular}{ccccc} 
Variables & $\beta$ - coefficient & OR & IC & p-Value \\
\hline Age & 0.0646 & 1,098 & $(0,514-2,156)$ & $<0.001$ \\
\hline Male & 0.1109 & 1,157 & $(0,719-2,475)$ & $<0.001$ \\
\hline LOS & 0.3535 & 2,513 & $(1,812-5,293)$ & $<0.001$ \\
\hline ICU stay & 0.1836 & 1,365 & $(1,015-3,193)$ & $<0.001$ \\
\hline $\begin{array}{c}\text { number of } \\
\text { departments }>1\end{array}$ & 0.0305 & 1,012 & $(0,364-1,571)$ & $<0.004$ \\
$\begin{array}{l}\mathrm{R}^{2}=0.3861 \\
\text { OR - Odds Ratio; IC - Interval Confidence } \\
* \\
\text { p-Value - statistical significance for multivariate logistic regression }\end{array}$ & & \\
\end{tabular}


Tab. 4 Clinical Value Units for patients within DRG

\begin{tabular}{ccc}
\multirow{2}{*}{ DRG } & \multicolumn{2}{c}{ CVU } \\
\cline { 2 - 3 } & Mean (sd) & Total \\
\hline N09 & $9.39(2.34)$ & 4429.38 \\
\hline M15 & $4.88(1.56)$ & 1666.62 \\
\hline B19 & $5.12(1.67)$ & 2832.45 \\
\hline E27 & $5.45(1.99)$ & 2693.41 \\
\hline E12 & $6.27(2.06)$ & 3181.52 \\
\hline B18 & $5.52(1.68)$ & 2764.04 \\
\hline N07D & $8.03(2.58)$ & 3404.75 \\
\hline A48 & $9.07(2.84)$ & 5043.79 \\
\hline N03 & $19.01(3.97)$ & 10903.54 \\
CVU- Clinical Value Unit; DRG - Diagnosis Related Groups
\end{tabular}


Tab. 5 Cost estimates for the Clinical Value Unit (CVU), Length of Stay (LOS) and Marginal Mark-up method

\begin{tabular}{|c|c|c|c|c|c|c|c|c|c|c|}
\hline \multirow{2}{*}{ DRG } & \multirow{2}{*}{$\begin{array}{c}\text { Direct costs } \\
\text { Mean (SD) } \\
{[€]}\end{array}$} & \multicolumn{3}{|c|}{$\begin{array}{l}\text { Indirect costs } \\
\text { Mean }(\mathrm{SD})[€]\end{array}$} & \multicolumn{3}{|c|}{$\begin{array}{c}\text { Total costs } \\
\text { Mean }(\mathrm{SD})[€]\end{array}$} & \multicolumn{2}{|c|}{$\begin{array}{c}\text { Mean difference compared to } \\
\text { CVU }[€]\end{array}$} & \multirow[b]{2}{*}{ p-value } \\
\hline & & CVU & LOS & $\begin{array}{l}\text { Marginal } \\
\text { Mark-up }\end{array}$ & $\mathrm{CVU}$ & LOS & $\begin{array}{l}\text { Marginal } \\
\text { mark-up }\end{array}$ & LOS & $\begin{array}{l}\text { Marginal } \\
\text { mark-up }\end{array}$ & \\
\hline N09 & $\begin{array}{c}779.27 \\
(786.45) \\
\end{array}$ & $\begin{array}{l}1,111.80 \\
(419.97) \\
\end{array}$ & $\begin{array}{l}1,971.76 \\
(945.28) \\
\end{array}$ & $\begin{array}{c}626.12 \\
(631.88) \\
\end{array}$ & $\begin{array}{l}1,891.08 \\
(942.03) \\
\end{array}$ & $\begin{array}{l}2,751.04 \\
(1311.24)\end{array}$ & $\begin{array}{l}1,405.39 \\
(1418.34) \\
\end{array}$ & $\begin{array}{c}859.96 \\
(528.55) \\
\end{array}$ & $\begin{array}{l}-485.68 \\
(708.02)\end{array}$ & $\begin{array}{l}=0.001^{*} \\
=0.001^{* *}\end{array}$ \\
\hline M15 & $\begin{array}{c}78.85 \\
(97.11)\end{array}$ & $\begin{array}{l}418.33 \\
(106.17)\end{array}$ & $\begin{array}{l}158.15 \\
(44.70)\end{array}$ & $\begin{array}{c}60.94 \\
(78.02)\end{array}$ & $\begin{array}{l}494.18 \\
(151.74)\end{array}$ & $\begin{array}{c}234.01 \\
(124.25)\end{array}$ & $\begin{array}{c}136.80 \\
(175.13)\end{array}$ & $\begin{array}{l}-260.17 \\
(107.89)\end{array}$ & $\begin{array}{l}-357.38 \\
(124.48)\end{array}$ & $\begin{array}{l}=0.001^{*} \\
=0.001^{* *}\end{array}$ \\
\hline B19 & $\begin{array}{l}394.95 \\
(89.72) \\
\end{array}$ & $\begin{array}{l}710.96 \\
(94.39) \\
\end{array}$ & $\begin{array}{c}293.27 \\
(150.17) \\
\end{array}$ & $\begin{array}{l}317.33 \\
(72.08) \\
\end{array}$ & $\begin{array}{l}1,105.91 \\
(144.69)\end{array}$ & $\begin{array}{c}688.22 \\
(198.66) \\
\end{array}$ & $\begin{array}{c}712.27 \\
(161.80) \\
\end{array}$ & $\begin{array}{l}-417.69 \\
(102.57)\end{array}$ & $\begin{array}{l}-393.63 \\
(104.45)\end{array}$ & $\begin{array}{l}=0.001^{*} \\
=0.001^{* *}\end{array}$ \\
\hline E27 & $\begin{array}{c}476.91 \\
(401.78)\end{array}$ & $\begin{array}{c}676.06 \\
(100.96)\end{array}$ & $\begin{array}{c}400.46 \\
(150.63)\end{array}$ & $\begin{array}{c}383.18 \\
(322.81)\end{array}$ & $\begin{array}{l}1,152.97 \\
(419.39)\end{array}$ & $\begin{array}{c}877.38 \\
(436.04) \\
\end{array}$ & $\begin{array}{c}860.10 \\
(724.59) \\
\end{array}$ & $\begin{array}{c}-275.60 \\
(107.31) \\
\end{array}$ & $\begin{array}{l}-292.87 \\
(333.12) \\
\end{array}$ & $\begin{array}{l}=0.001^{*} \\
=0.001^{* *}\end{array}$ \\
\hline E12 & $\begin{array}{l}2,023.03 \\
(748.66) \\
\end{array}$ & $\begin{array}{c}798.58 \\
(168.62) \\
\end{array}$ & $\begin{array}{c}667.76 \\
(315.50) \\
\end{array}$ & $\begin{array}{l}1,625.44 \\
(601.52) \\
\end{array}$ & $\begin{array}{l}2,821.62 \\
(762.30) \\
\end{array}$ & $\begin{array}{l}2,690.80 \\
(830.72) \\
\end{array}$ & $\begin{array}{l}3,898.47 \\
(1350.18)\end{array}$ & $\begin{array}{l}-130.82 \\
(186.87) \\
\end{array}$ & $\begin{array}{c}826.86 \\
(629.72) \\
\end{array}$ & $\begin{array}{l}=0.001^{*} \\
=0.001^{* *}\end{array}$ \\
\hline B18 & $\begin{array}{c}404.73 \\
(106.97) \\
\end{array}$ & $\begin{array}{c}693.79 \\
(155.31) \\
\end{array}$ & $\begin{array}{c}341.46 \\
(248.52) \\
\end{array}$ & $\begin{array}{l}325.19 \\
(85.95) \\
\end{array}$ & $\begin{array}{l}1,098.52 \\
(214.05) \\
\end{array}$ & $\begin{array}{c}746.20 \\
(302.64) \\
\end{array}$ & $\begin{array}{c}729.92 \\
(192.92) \\
\end{array}$ & $\begin{array}{c}-352.32 \\
(154.57) \\
\end{array}$ & $\begin{array}{l}-368.60 \\
(152.55)\end{array}$ & $\begin{array}{l}=0.001^{*} \\
=0.001^{* *}\end{array}$ \\
\hline N07D & $\begin{array}{c}320.64 \\
(685.02)\end{array}$ & $\begin{array}{c}854.61 \\
(377.08)\end{array}$ & $\begin{array}{l}1,413.46 \\
(844.50)\end{array}$ & $\begin{array}{c}257.63 \\
(550.39)\end{array}$ & $\begin{array}{l}1,175.25 \\
(808.93)\end{array}$ & $\begin{array}{c}1,743.11 \\
(1130.43)\end{array}$ & $\begin{array}{c}578.27 \\
(1235.41)\end{array}$ & $\begin{array}{c}567.86 \\
(321.50)\end{array}$ & $\begin{array}{l}-596.98 \\
(426.48)\end{array}$ & $\begin{array}{l}=0.001^{*} \\
=0.001^{* *}\end{array}$ \\
\hline A48 & $\begin{array}{c}525.89 \\
(424.20)\end{array}$ & $\begin{array}{l}1,266.02 \\
(246.51)\end{array}$ & $\begin{array}{l}1,628.95 \\
(504.89)\end{array}$ & $\begin{array}{c}422.54 \\
(340.83)\end{array}$ & $\begin{array}{l}1,791.91 \\
(545.74)\end{array}$ & $\begin{array}{l}2,154.84 \\
(757.54)\end{array}$ & $\begin{array}{c}948.42 \\
(765.04)\end{array}$ & $\begin{array}{c}362.93 \\
(211.80)\end{array}$ & $\begin{array}{l}-843.49 \\
(219.30)\end{array}$ & $\begin{array}{l}=0.001^{*} \\
=0.001^{* *}\end{array}$ \\
\hline N03 & $\begin{array}{l}1,135.75 \\
(796.22)\end{array}$ & $\begin{array}{c}2,736.85 \\
(1509.67)\end{array}$ & $\begin{array}{c}5,653.38 \\
(3414.14)\end{array}$ & $\begin{array}{c}912.54 \\
(639.74)\end{array}$ & $\begin{array}{c}3,872.61 \\
(2020.09)\end{array}$ & $\begin{array}{c}6,789.13 \\
(3865.99)\end{array}$ & $\begin{array}{c}2,048.30 \\
(1435.97)\end{array}$ & $\begin{array}{c}2,916.52 \\
(1845.90)\end{array}$ & $\begin{array}{l}-1,824.31 \\
(-584.12)\end{array}$ & $\begin{array}{l}=0.001^{*} \\
=0.001^{* *}\end{array}$ \\
\hline
\end{tabular}

${ }^{*}$ Wilcoxon signed ranks Z-test CVU to LOS; ${ }^{* *}$ Wilcoxon signed ranks Z-test CVU to marginal mark-up; CVU- Clinical Value Unit; DRG - Diagnosis Related Groups; LOS Length of Stay 
Tab. 6 Coefficient of homogeneity of costs for CVU, LOS and Marginal Mark-up method.

\begin{tabular}{cccc}
\multirow{2}{*}{ DRG } & \multicolumn{3}{c}{ CH [\%] } \\
\cline { 2 - 4 } & CVU & LOS & Marginal Mark-up \\
\hline N09 & 0.6675 & 0.6772 & 0.4977 \\
\hline M15 & 0.7651 & 0.6532 & 0.4386 \\
\hline B19 & 0.8843 & 0.7760 & 0.8149 \\
\hline E27 & 0.7333 & 0.6680 & 0.5428 \\
\hline E12 & 0.7873 & 0.7641 & 0.7299 \\
\hline B18 & 0.8369 & 0.7114 & 0.7910 \\
\hline N07D & 0.6938 & 0.6259 & 0.3189 \\
\hline A48 & 0.8370 & 0.7634 & 0.5535 \\
\hline N03 & 0.6444 & 0.6235 & 0.5879
\end{tabular}

$\mathrm{CH}$ - coefficient of homogeneity; CVU- Clinical Value Unit, DRG - Diagnosis Related Groups; LOS - Length of Stay 